\title{
The Rise and Tide of the Minangkabau Traditional Trading in Kuala Lumpur: A Preliminary Research
}

\author{
Sismudjito, Rizabuana Ismail and Darul Amin Abdul Munaf
}

Received: 02012015 / Accepted: 0502 2015 / Published online: 30062015

(c) 2015 Faculty of Geography UGM and The Indonesian Geographers Association

\begin{abstract}
This article is discussing on how the rise and tide of Minangkabau traditional trading occur in Kuala Lumpur. The research focused on four areas in Kuala Lumpur, Chow Kit, Kampung Baru, Kampung Dato' Keramat and Mesjid India area, reveals that there are some small stalls of Minangkabau traditional trading are now owned by another Indonesian ethnicity such as Acehenese and Boyanese tribe. Meanwhile, some of the businesses are still possessed by Minangkabau tribe such as Nasi Padang and textile trading. The phenomenon is affected by the lack of business innovation, capital, local competitor and the fact that they are unable to follow the trend in business. Even though, there are some of well-developed traditional business run by Minangkabau people in Kuala Lumpur due to the existence of marketing creativity, innovative items, and the conducive partnership with another Minangkabau entrepreneurs in the textile merchant in form of kiosk or arcade in Mesjid India area that has connection with another counterpart of the nationwide including Sabah and Sarawak.
\end{abstract}

Keywords: Minangkabau, Traditional trader, Trading, Kuala Lumpur

Abstrak Artikel ini membahas tentang bagaimana kebangkitan dan gelombang perdagangan tradisional Minangkabau di Kuala Lumpur. Penelitian difokuskan pada empat lokasi di Kuala Lumpur yaitu Chow Kit, Kampung Baru, Kampung Dato' Keramat dan Masjid India. Temuan awal menunjukkan bahwa ada beberapa warung tradisional kecil orang Minangkabau yang sekarang dimiliki oleh etnis lain dari Indonesia seperti Aceh dan suku Boya. Sementara itu, beberapa bisnis lain masih dimiliki oleh suku Minangkabau seperti Warung Nasi Padang dan perdagangan tekstil. Fenomena tersebut dipengaruhi oleh kurangnya inovasi bisnis, modal, pesaing lokal dan fakta bahwa mereka tidak dapat mengikuti tren dalam bisnis. Meskipun, ada beberapa bisnis tradisional yang berkembang dengan baik, yang dijalankan oleh orang-orang Minangkabau di Kuala Lumpur karena adanya kreativitas pemasaran, item yang inovatif, dan kemitraan yang kondusif dengan pengusaha Minangkabau lain di merchant tekstil berupa kios atau akad di Mesjid India, yang memiliki hubungan dengan mitra lain secara nasional termasuk Sabah dan Sarawak.

Kata kunci: : Minangkabau, pedagang tradisional, Perdagangan, Kuala Lumpur

\section{Introduction}

The Minangkabau traders came to Kuala Lumpur four decades ago to run business in informal sectors in four main locations, those are Kampung Baru (Pasar Minggu, Jalan Raja Alang, Jalan Tuanku Abdul Rahman and Jalan Chow Kit), Kampung Dato' Keramat, Gombak and Wisma Yakin Building or known as Jalan Mesjid India. Since the fist coming, the Minangkabau traders focused their business in four main types of business what so called traditional trading of Minangkabau; first is on food that is known as Nasi Padang or Padang Restaurant; second is on textiles trading such as sarong, veil, shawl, and so forth; third is on handicraft such as songkok, shoes, capal and working as a tailor; and last thing is running a grocery store that provide many households needs and also traditional remedy such as

Sismudjito, Rizabuana Ismail

Universitas Sumatera Utara

Email: dihermon006@gmail.com

Darul Amin Abdul Munaf

Universitas Kebangsaan Malaysia herbal medicine.

This article will discuss on how the rise and tide of this traditional trading of Minangkabau people in Kuala Lumpur. There are three problems has been researched that become the focus of this article. The first question is regarding to whether or not the kinds of business of Minangkabau is lesser? the second is what are the kinds of traditional trading that expand?, and the last one is what are the factors affecting the rise and tide of the traditional trading of Minangkabau people in Kuala Lumpur?

\section{The Methods}

The four types of trading mentioned above are typical of the traditional trading of Minangkabau people in Indonesia. The question towards this phenomenon is why does the type of trading known as the traditional trading of Minangkabau people? There are at least two main characteristics of this trading being categorized as the traditional trading of Minangkabau. The first characteristic is the kinds of business that exist since 
the first time the trader came in to Kuala Lumpur and being inherited from one to another generation especially in the Minangkabau family. Two types of traditional business run by the Minangkabau people are on textile and food that is known as Padang Restaurant. According to Dobbin [1977], the activity of weaving among the Minangkabau people has begun hundreds years ago until 'the Netherlands' government came and once stopped the activity up to the end of Paderi war on 1837. This condition also happened to the Restaurant Padang business which is one of the inherited business traditions for many years. These businesses are known in every corner of Indonesia as well as in Malaysia and have created a network of Restaurant Padang throughout Indonesia due to the experienced and developed business factors. Denys Lombard [1996] and Joel. S. Kahn [1980] argued that Restaurant Padang business is kind of deep-rooted activity among Minangkabau people and becomes their business network in Indonesia.

The second characteristic is the procedure of market business as the uniqueness of the traditional trading of Minangkabau people. According to Clifford Geertz [1963; 1965], the features of market business procedures are the meeting between seller and buyer, the small business pattern, and the using of cash in every act. Usman Pelly [1998] on his research pertaining to the mission of Minangkabau people sojourn to Medan which held their business with no capital. He found some deposited goods to be sold or what so called galeh amanah that usually practiced by Minangkabau people in West Sumatra and some other cities such as Jakarta and Bandung.

There are some assumptions stating that the Minangkabau people tend to be entrepreneur compared to the other ethnicity group in Indonesia. Mochtar Naim [1979] has classified three categories of profession that the Minangkabau people usually do during sojourning those are entrepreneur, employee (civil servant, private company employee or army) and in the field of education (teacher or lecturer). His research on those three professions has revealed that $65 \%$ or equal to two third of the respondents prefer to run their own business which can show their high motivation and competition ability. Kahn [1980] stated that the Minangkabau people are persistent group in trading. Moreover, they are admitted as the very potential group to tie networking as well as Chinese. Therefore, Denys Lombard [1996] and Furnivall [1944] have categorized them as native Indonesia with entrepreneur potential to compete with Chinese.

Those assumptions might be true even though it may become common perception due to many people can find the Minangkabau people trade in the markets. Otherwise only small number of the Minangkabau people involve in the corporate sector in big company. Therefore, there are some points of view stating that not all of the Minangkabau people prefer to deal with business. Some people extremely see that the Minangkabau people not only run the business because of the entrepreneurship factor per se, but also to set them free in doing something. The most important thing is being free from certain party, therefore they prefer to set up business and do self-employment due to the existence of self character of being free. Taufik Abdullah [1971], and Kato [1982] are some of Minangkabau society found out the other aspects that become the reason why the Minangkabau people choose informal business as their career. They have similar opinion that being free and not being tied up with other party is the characteristic of the Minangkabau people.

This research was conducted in Chow Kit, Kampung Baru, Gombak and Dato' Keramat areas by using participant observation and interview techniques. Some Minangkabau traditional traders who have been permanently staying or living in Kuala Lumpur for more than two decades were interviewed. Besides, interviews were also conducted toward the key informants, the Minangkabau people or the family who have been recognized as citizen of Malaysia, born in Malaysia or living for many years. I have observed their existence as entrepreneurs in Malaysia for quite sometimes. In the middle of 1986, when I took Master Program at Universiti Kebangsaan Malaysia, I noticed quite numbers of the Minangkabau people were running business at night markets and grocery store around Kuala Lumpur. Otherwise, when I took my Post Graduate Program in another year, 1998, the progress of their businesses has changed into formal and formed chains of clothing and textile business in kiosks, known as arcade (aked) in Malaysia, as in Tanah Abang and Central Market in Medan. In another word, the traditional trading of the Minangkabau people has developed and transformed from street vendor into merchant. This research was conducted in two phases, March - May 2009 and October - November 2009.

Wisma Yakin Building is the first place where the Minangkabau people run their business in Kuala Lumpur. The Minangkabau traders have assumed this building as little Indonesia where some of the traders here are Indonesian. The kiosk and stores are similar to the traditional market in Indonesia. Moreover, the kiosks here are using the term toko, means kiosk or store, for the board such as Toko Batik Indonesia established since 1970 and Restoran Padang Waspada that took the name from one of the famous newspapers in Medan. Little Indonesia identity formation in this area has certain purposes, for nostalgia and memory. The most important thing about the identity is to show that not all of the traders are Indian even though the building once became the centre of Indian traders since the Independence of Malaysia. There are Mesjid India, Mesjid Jamek, Jalan Tun Perak and close to Lebuh Ampang as the centre of Indian traders up to now. Therefore, the identity of Little Indonesia is needed as the separate line between Little India that was built by 
Indian people surrounding Wisma Yakin.

In order to attract Malay citizen to visit this area,

Wisma Yakin was built as trading centre and given Malay name to the street for easy recognition, even the traders are mostly consists of the Minangkabau people. The question that may come out is why do the Minangkabau people could be based in this area? It is simply because the small number of Malay people who involved in business, but most of them focused on services sector or civil servant in early 1970s. The owners of Wisma Yakin do not really understand the Minangkabau culture, even they are coming from that tribe, it is because most of them were not born in the Minangkabau area. Most of the owners came from Medan since the occupation of Japan and some sojourned to Singapore since the British colonial. They came to Malaysia after the separation of Singapore and Malaya in 1963. Therefore, the Minangkabau people are now running their business here and being recognized as citizen of Malaysia [Darul Amin Abdul Munaf, 1989]

Many kind of the Minangkabau people's traditional products are sold in Wisma Yakin such as Nasi Padang, handicraft such as songkok, shoes, capal and veil, clothing and traditional medicine including herbal [Darul Amin Abdul Munaf, 1989]. Those trading material are imported from Indonesia. The Minangkabau traders buy those items from Indonesian people that are usually called pedagang babelok or circular trader who are selling their products to the stores in Wisma Yakin. The products are usually not fully paid by the buyer, only half of the amount stated, the balance will be cleared when the circular trader come in another day that usually have a fix schedule to visit and offer any other products.

Sometimes the kiosk owner feel unsatisfied with the colour or the product, as the consequences of the condition, some of the Minangkabau trader go to Medan, Jakarta or Padang to buy the products they wanted. By doing so, they are not only can find any products they intend to buy but also can use the opportunity to meet their family in Indonesia. Nevertheless, this was no longer working for some of the trader who has no relatives in Indonesia due to the need of place to stay in some length of time to find the products. Some of them were tricked by the seller in Indonesia, which is why having relatives is quite helping to process trading activity and shipping the product to Kuala Lumpur.

Most of the traders who usually went to Indonesia for buying products are coming from Medan in 1970s, some of them are coming from Kota Matsum (KOMAT) and from Gang Meriam, Sungai Mati behind Istana Maimoon, Medan because their relatives who came and run business in Wisma Yakin and some of them stayed in Pasar Minggu Kampung Baru, Kampung Selayang Baru. hence, the Gang Meriam Connection or Ajo connection exists as the centre of the Minangkabau Pariaman for producing some handicraft, clothing and shoes. This relationship got close when the Gang
Meriam was offered to work and stay in Malaysia and also supply handicraft to Wisma Yakin with highly paid. They will be provided by the raw material and the important thing was that they acted as the designer, not the handicraft worker.

At that time, they were also promised to have Identity Card as permanent resident or Red Identity Card and have a place to live in Kuala Lumpur. As the consequences, the trader should come without family. Unfortunately the unwritten agreement was not fully obeyed. In the end, the traders were the one who design, make the products and also sell them or even stay in the kiosk all night long. The wages they got could only fulfil the daily needs and cover the phone call bill to their family. The desire to go back to their hometown lately became an impossible thing to do since the travelling documents were kept by their employer. When they got their Identity Card, around 1979, none of the traders were willing to tie a relation with anyone in Wisma yakin. The Gang Meriam and Ajo Connection people then found any other job opportunities regarding to their traditional business ability. Some of them were posted in Chow Kit area as street vendors.

\section{Restoran Padang Business}

Restoran Padang is one of the pioneer businesses run by the Minangkabau people. Their involvement in this business were begun from the very beginning and went through every step of business pathway. Some of them could run a formal restaurant due to their financial support. Generally, the Minangkabau traditional trading can be drawn through five steps, those are: (a) home food business, (b) night market food stalls business, (c) street vendor food business, (d) Padang food in Chinese Restaurant and (e) Padang Restaurant.

\section{(a) Home Food Business}

Most of the Minangkabau food businesses are started from home in order to keep survive on their sojourn. Principally, the business can help the breadwinner in fulfilling the need of food's cost. This business also may help the family to earn more income. They are usually providing breakfast meals in the morning and snacks in the afternoon and evening; if they may not able to sell the whole foods, then it might be the family meals. This business usually runs by the housewife and helped by the children in order to reduce cost. At the same time, the husband will also do another business such as becoming a tailor and making handicraft for extra money.

\section{(b) Night Market Food Stalls Business}

The foods' stalls in night market are usually owned by the sojourners who have become permanent citizen with Identity Card. Referring to the Local Government Act regarding to own a business, the one who have Identity Card will be easier to prepare their products 
at home, buy the raw material and carry it from one place to another. Home cannot be a production based due to safety reasons. The process of selling product at night market is not strict due to the loose-regulation in every market. Night market management are different from one to another that may affect to the different regulations. Some markets are controlled under Majelis Perbandaran and Dewan Bandaraya, but some are under political party and private which do not need any license to run a business unless the trader pay the rent. In this context, Chow Kit is not considered as night market even the activity is occurring every night. It is considered as permanent night market, known as street vendors night market.

\section{(c) Street Vendor Food Business}

Wherever street vendor stalls are standing, there must be the Minangkabau traders there as well as in Kuala Lumpur. They are selling Padang foods on the stall. There were 10 to 15 Minangkabau people's stalls at Chow Kit night market in 1980s. Business in Malaysia must be run permanently with license from the authorized party, Dewan Bandaraya Kuala Lumpur. The applicants must be the citizen of Malaysia. As the consequences of certain situation, most of the Minangkabau people hired local person to apply the license known as business license Ali baba. The using of business license like this is common in street vendor Kuala Lumpur, especially Chow Kit area. Food business is very promising in Chow Kit area; the vendor can prepare and cook on the spot due to the quite number of consumers rather than home food business. This food business area usually opened at 10 am in the morning until $12 \mathrm{pm}$ in the evening.

\section{(d) Padang Food in Chinese Restaurant}

This kind of business was the toll ticket to solve business license problem at that time. The Minangkabau trader usually shared or rented one spot in Chinese restaurant. There were many Chinese people cooperated with the Minangkabau people to run Padang Restaurant in 1970s. The Chinese not only got rented payment from the Minangkabau people but also could operate the drinking stall which gave benefit in restaurant business. We can assure that the consumers who come to the restaurant will at least order something to drink; they are not always coming to have a meal. This kind of cooperation is seen as something mutual, winwin solution, due to the transportation consideration, business license and the unfixed place.

\section{(e) Padang Restaurant}

There was limited number of trader who opened their own restaurant in 1970s, not only because of the difficulties in financial matter and having license but this business also give high risk for trader to deal with the consequences that might occur. There will be nothing to afraid of if the business runs very well, but another story might happen if it is not what they expect it is, besides may harm the business. There were just small number of the Minangkabau people who owned their own Restaurant due to the difficulties in rented the place and license, moreover if the people is not stated as citizen yet in the country. Restaurant Waspada at Wisma Yakin, Restaurant Sudi Mampir, Restaurant Omar Bahagia and several other restaurants on Dato'Keramat that were run to sell Nasi Padang or Nasi Ayam.

\section{Clothing and Textile Business}

Clothing and textile business is another traditional business that earlier run by the Minangkabau people in Kuala Lumpur. The establishment of this business was in the various innovative forms of products and way of trading that can be divided into five; those are (a) auction trading, (b) night market trading, (c) street vendor trading, (d) fixed store trading and (E) aked trading.

\section{(a) Auction Trading}

Auction trading is kind of new creation of selling around 1979 in Kuala Lumpur. It was similar to the system of street vendor medicine/remedy selling. Pattern of selling is by mixed up the clothing and mentioned the price which can be cut many times until the trader reach his final price and counted 1 to 10 for time limit. If there is no one who will buy the cloth, then he will cut the price into the maximum limit by mixing the type of clothing and give additional gifts such as perfume to attract consumer. If there is still no one who are interested to buy, then one of his friend will act as if he buy the cloth. The trader must be very wise and attractive in selling the goods.

This kind of trading is shared by group for selling and moving from one market to another that become the centre of numerous of people. Therefore, they have to make demonstration in order to attract people to come. Some friends are invited too and will leave the place when there are enough crowds to sell the product. In the end, there will be the trader and consumer who are on the spot.

\section{(b) Night Market Trading}

The business of selling cloth in night market is similar to selling food which should be carried from one to another place in different night market every day. The clothing will be kept in their house and carried out in the afternoon for selling. This routine will be the same every day, place of selling is the only different thing they faced. The supplier is usually pedagang babelok that routinely coming from Indonesia.

\section{(c) Street Vendor Trading}

This clothing street vendor is also similar to the one who are selling food, the different is that they will close and carry the goods in certain time while food seller do 
not. The goods will be carried by using pushcart and kept them in the store close by. For them who are always carrying back the goods, they usually have their own or rent for transportation, van or lorry, to cope with the situation. This phenomenon usually happened in Chow Kit area. They will find and rent storage to keep the goods, and this will be filled with several pushcarts. This rented storage is usually monthly paid, and the owner will give the storage's key for every tenant. The trader here is the same as the food seller who rent the Ali Baba license from the local citizen.

\section{(d) Fixed Store Trading}

There only small number of trader who posses their own store due to the Identity Card problem which is causing difficulties in buying a store or kiosk. Meanwhile, they are also unable to rent a store because of the high rent rate and the amount of deposits which totally can be equal to the down payment for buying a store.

\section{(e) Aked Trading}

Aked trading is a new transformed model of selling clothing in Kuala Lumpur which is similar to the trading in Tanah Abang in Jakarta and Central Market in Medan or some other places in Indonesia. The Aked was established in the limited corporation form. The store was bought by cooperating with local citizen, Ali Baba system, in order to facilitate Bank Loan. Ali Baba system is used in order to avoid the recognition of other party toward this business. After the store purchasing is released and $10 \%$ of advance payment to the former owner, the store will be renovated and divided into several parts measures $8 \times 8$ feet that facing each other. The other 6 feet space is provided for the consumers. Mostly, the front area of the kiosk width measures 22 feet and length of 80 feet that can be separated into 20 kiosks.

The $10 \%$ advance payment is taken from the kiosk tenant who paid the unofficial booking fee in amount of RM 15,000.00 up to RM 20,000.00 for every unit; depend on the location of the kiosk. Many of the Minangkabau people prefer to rent the kiosk for they do not have to deal with license administration; the owner will do. Besides, the tenant will also be facilitated by the owner in the matter of transportation to carry their goods. The level of interest of renting aked was quite high in late 1990s.

Along Jalan Tuanku Abdul Rahman up to Jalan Mesjid India, there are tens of buildings are being renovated into aked. This phenomenon was spreading to the whole Malaysia including Sabah and Sarawak. The owner will gain bulk profits every month from the rental in amount of RM 1,500 up to RM 2,000 per unit. In other words we can say that the aked owner does not need to look for any employee to sell their products which are imported from Indonesia.

\section{Handicraft Business}

Some of the handicraft employee went back to their hometown right after the conflict with the Wisma Yakin administrator, but many of them keep stay due to their status as permanent resident. Some of them stayed in order to try another speculation in this country or felt ashamed of return home so that the Minangkabau people from Komat and Gang Meriam rented house around Kampung Baru, Datuk Keramat and Selayang Baru. Most of them were selling capal, being a tailor to produce cloth and songkok. Almost all of them were creating and selling their own product by themselves or sent it to certain store or boutique.

\section{(a) Own Production and Selling}

The production of handicraft can be found in the area of Pasar Minggu and Kampung Baru, nearby Chow Kit in order to sell the products, where songkok, Malay traditional outfit, capal and sewing shop may be found. The trader usually brought and sold their products here as street vendor every evening in the Chow Kit night market. The sales of goods are usually increased in some occasions, different from the weekdays selling, such as Aidil Fitri since due to the needs of attributes for that celebration. They usually find that selling the products to certain store may create difficulties in payment meanwhile they bought the raw material for making the products in cash, so that they prefer to sell their product directly to the consumer. In 1980s, there were more or less 10 people who sell capal in Chow Kit area. They used pedicab, three wheel motorcycle, and pushcart to carry their goods.

\section{(b)Selling Products to the Shops}

This kind of selling was done by trader from Gang Meriam on their first coming. Since the agreement was not obeyed by the administrator of Wisma Yakin, as the consequences of certain condition then the cooperation was not able to be continued. Therefore, they prefer to sell their own products directly. Lately, there were several stores owned by the Minangkabau trader in the end of 1980s that will buy the handicraft, capal and songkok in cash. The trader in Jalan Perkins and Dato' Keramat has connection to distribute the capal and songkok to Singapore. The traders consist of three people; they are Man Capal (Sudirman), Uda songkok, and Azhar Ahmad who were exporting the products to Singapore. The rest are sold to store and boutique located in Bangunan Hock Ann at Jalan Haji Hussein, Chow Kit that is known as Anang Enterprise in Kuala Lumpur.

\section{Grocery Store (Kelontong)}

Peddler business is a kind of traditional trading that's not well-established among Minangkabau people in Malaysia. Elder people were usually involved in this kind of business in order to sell traditional medicine or remedy, herbal, cigarette and snack for their leisure 
time. The peddler is also used as a place for them to meet or nostalgia. This kind of business was not inherited to the next generation of family, even though the children were raised in the business circumstances, eventually they have no willingness to conduct the same business. Therefore, when the peddler owner has passed away, the business will face the same way. The store will be rented or sold. The Minangkabau trader who are involved in this sector usually have been recognized as citizen. Their store could be found in Dato' Keramat area, Gombak, Kampung Baru and Kajang in Kuala Lumpur, but it is now in the hand of Acehnese traders.

\section{Result and Discussion}

The life of Minangkabau people in Kuala Lumpur experienced the rise and tide in trading. Most of the Minangkabau people who sojourned to Malaysia two or three decades ago were graduated from Junior high school. Some questions are identified as obstacles, as follows:

First, the majority respondents stated that business license become the obstacle, even if they are already recognized as permanent resident. They could not run any business unless registered and owned a license. If they keep on running business illegally, they will be punished. This is actually not a proper question since there are many Minangkabau people may open their own business with the consequences that they possess a company to be the consideration of issuing license.

This phenomenon appear when many sojourners from Indonesia come and run a new business such as Restaurant Ayam Penyet, Restaurant Bali and any other Indonesian traditional foods. They can successfully open a new business due to have a company which is audited and regularly paying tax to the government. Meanwhile most of the Minangkabau people do not know about the regulation, because of their educational background and lack of information about modern business in Malaysia. Therefore, some of them were chased by Dewan Bandaraya enforcement, Majelis Daerah or local administrator pertaining to their license.

The second reason is high rental fee factor. The Minangkabau people are lack of motivation due to the low educational background and high rental fee factor; therefore they could only be the street vendor. They were obstructed by fear of being assaulted and they lose their money to Ali Baba for their help of issuing the license. This phenomenon was even worse when the administrator or enforcement did the spot check accompanied by the heavy rain which may affect to the less number of consumers who visit the store. Their income could only fulfil their basic needs; we can call them by using Minangkabau proverb as Pai Ampok Pulang Aban or no results.

The third reason is there are competition with local and Indonesian traders who has more innovation in selling products. The local trader were involved as street vendor in Malaysia in the middle of 1980s when monetary crisis happened in Malaysia and there were number of people from rural area moved to Kuala Lumpur. Malaysian government has initiative to create some regulations of business administration by establishing an organization, business fund support, business training and so forth. The Minangkabau people are considered as enthusiastic, but in fact the spirit per se is not enough to run business, moreover they are staying abroad. They were forced to move from the Federal Territory of Kuala Lumpur due to the Persatuan Penjaja Wilayah Persekutuan (Federal Territory Hawkers Association) led by Mr. Ibrahim bin Abdul Razak as a president has filtered between sojourn and local traders. Eventually, the Minangkabau traders were forced to move from Kuala Lumpur.

Overall, there are only three left out of four kinds of traditional trading of the Minangkabau people in Kuala Lumpur.

The traditional trading that lost from the Minangkabau people in Kuala Lumpur is grocery or kelonthong business. It is quite difficult to find any Minangkabau people who run peddler as their business. This kind of business nowadays is mostly run by Acehenese people. The Minangkabau people used to compete with Chinese, but today the Chinese will face that Acehenese people as their competitor. Acehenese trader has now control all kinds of business in medicine, herbal remedy and small kiosk, known as peddler in Kuala Lumpur, and Malaysia as a big area for sure. They are considered as more innovative and have an established organization that may help. The new traders from Aceh mostly were helped by the wealthy Aceh leader. The Aceh traders were not influenced by the status of being citizen or not, a little bit different compared to Minangkabau traders. Moreover, Aceh traders are suggested to get married with local citizen in order to establish their business in this country. Besides, Malaysian Government seems more open to Aceh traders compared to Minangkabau, moreover after the occurrence of tsunami in 2004. Aceh people were allowed to move into Malaysia, given Tsunami Card and provided a place for running business in Chow Kit area and another places in Malaysia. Peddler business were taken over by Boyanese around Dato' Keramat, one of the famous traders namely Anwari who is originally from Boyan. The most important from the whole over story is that peddler must be run in modern way by establishing a real company. In other words, we can see that there are many peddler in a form of corporate company along Jalan Raja Alang and Kampung Baru which are controlled by private limited company or enterprise.

Handicraft business, such as the making of capal and songkok, and Padang Restaurant are the enduring businesses that are conducted by Minangkabau people. These are quite miserable business which could not be well developed due to lack of consumerism unless there 
will be any celebration, Idul Fitri for instance. Besides, the products are less favoured. Most of people are now wearing ketayap better than songkok or sandals are preferable rather than capal to be worn with Malay traditional cloth, for example. Another aspect that may affecting is that the price of both products, capal and songkok. They are getting more expensive because of handmade products. Otherwise, the production of sandals and ketayap are using machine which is not only can reduce the production cost and time but also can produce large number of products rather than the handmade one.

Meanwhile, Nasi Padang is left behind due to the competition with many variations of food in every corner of the city. The development of fast food by multinational company may attract the executives to choose this kind of food rather than the traditional one, due to it's simplicity, fast and good taste, the restaurant usually offering a comfortable atmosphere equipped with air conditioner. Promotion package, promotion and affordable price, about less than RM 10.00 per package including drinking, that offered by Kentucky Fried Chicken, Mc Donald and A\&W may compete with the traditional restaurant. Padang Restaurant may not able to provide fresh food every time the costumers need it. It is different with Thailand restaurant that offer a freshly cooked Tom Yam. The most challenging for Padang Restaurant is Mamak Restaurant which is run by the India Moslem. The mamak restaurant can successfully attract the customers with the special drink (teh tarik). Mamak restaurant is always giving satisfied services with fastness and friendliness. They are accepting complaints which are different to Padang Restaurant. The old-fashioned service and approach is still applied in Padang Restaurant which affect other Indonesian restaurant in term of the same stereotype of services.

In fact, the society still put interest to try the Indonesian foods. Nowadays, there are many other Indonesian restaurants in Malaysia, but the stereotype does exist in every mind of customers. When Indonesian people are visiting Malaysia, the first place that will be searched is Padang Restaurant such as Sari Ratu and several restaurants with the same standard. In order to increase their income and services, Padang Restaurant owner tried to add some variations on foods such as Padang satay, Bakso and mix vegetables (gado-gado) as their menu. Some of the restaurants made standardization with local menu by providing Nasi Ayam, such as in Mars Nasi Ayam and Nasi Ayam Omar Bahagia at Dato' Keramat.

The business of Minangkabau people that are welldeveloped is on clothing in aked around Malaysia. The administration matter regarding to aked and tenant are managed by a corporate organization. If we could see clearly, the owner of aked is similar to the owner of hypermarket, and even higher since they treat the trader as their employee. Loan that is given by the owner to the tenant may tie both parties automatically. The tenant will depend on the owner for quite long time. In another side, the owner act as the importer of products from many other countries including Indonesia. The imported products are shared to every tenant or kiosk. Therefore, this phenomenon may create harmony among Minangkabau traders in Kuala Lumpur. Usman Pelly [1994] stated that this aked model has created some concepts in the Minangkabau traditional trading in form of consignment (galeh amanah), debt (galeh baparo) and capital circulation (mampalegakan pitih urang).

\section{Conclusion}

The Minangkabau traditional trading in Kuala Lumpur has experienced rise and tide. This research revealed that, among four kinds of traditional trading discussed above, grocery is controlled by Acehenese and people from Boyan. Meanwhile Padang Restaurant and handicraft have faced a very difficult situation as the effect of the transformed era that demand for high level of creativity and innovation. It is understandable that the lack of capital and the relation of Minangkabau people, especially the one with permanent resident identity, have affected the decline of Padang Restaurant and handicraft business. Besides, there are also policy in Malaysia pertaining to business license and organizational regulation that broke the Minangkabau business in Kuala Lumpur. If the patterns above can be solved as the clothing and textile business in aked, it may help the development of Minangkabau business; as the creative and innovative trading in aked market, capital circulation that mutual for both owner and tenant, has responsibilities in administrative matter such as license, and also build a good relationship among the Malaysian citizen and sojourn. The Minangkabau trader and business may be well developed and better if permanent resident communities and their Minangkabau political leaders in Malaysia are able to help and support, as Acehenese and Boyanese traders in Malaysia. 


\section{References}

Munaf, D.A.A, (1989), Pendatang Indonesia dan Implikasinya Terhadap Negara Malaysia (19701989): Kajian Kes di Kuala Lumpur, Latihan Ilmiah, Jabatan Sains Politik, Fakulti Sains Kemasyarakatan dan Kemanusian, Universiti Kebangsaan Malaysia, Bangi.

(2009), Perlindungan

Pembantu Rumah Indonesia di Malaysia: Antara Impian dan Realiti, in Mohammad Redzuan Othman (eds) Setengah Abad Hubungan MalaysiaIndonesia, Shah Alam: Arah Publications : 71-93.

Lombard, D (1996), Nusa Jawa: Silang Budaya, Jakarta: PT Gramedia Pustaka Utama Jil. II. Jaringan Asia.

Dobbin, C (1977), Economic Change in Minangkabau as a Factor in the Rise of the Padri Movement, 1784-1830, Indonesia 23:1-38.

Furnivall. J.S. (1944), Netherlands India : Study of Plural Economy. Cambridge: Cambridge University Press.

Geertz, C. (1963), Peddlers and Princess : Social Change and Economic: Modernization in Two Indonesian
Town. Chicago: Chicago University Press.

(1965), The Social History of an Indonesian Town, Massachusets Institute of Technology, Cambridge.

Kahn, J. .S. (1980), Minangkabau Social Formation. London: Cambridge University Press.

Kato, T (1982), Martiliny and Migration : Involving Minangkabau Tradtion in Indonesia, Ithaca: Cornell University Press.

Naim, M (1979), Merantau, Pola Migrasi Suku Minangkabau: Yogyakarta: Gadjah Mada University Press.

Abdullah, T (1971), School and Politics : The Kaum Muda Movement in West Sumatra (1927-1933) Monograph Series, Modern Indonesia Project: Cornell University, SEA Programe, Cornell University, Ithaca, New York.

Pelly, U (1998), Urbanisasi dan Adaptasi : Peranan Misi Budaya Minagkabau dan Mandailing, Jakarta : LP3ES. 